\title{
A STUDY ON THE SOCIAL NETWORK ANALYSES OF DIVE CENTERS AND SUSTAINABLE TOURISM DEVELOPMENT IN PEMUTERAN BALI, INDONESIA
}

\author{
Danis Arbabun NAJA* \\ Universitas Gadjah Mada, Faculty of Geography, Master Program in Planning and \\ Management of Coastal and Watershed, Yogyakarta, Indonesia, e-mail: danis.naja@gmail.com \\ Slamet SUPRAYOGI \\ Universitas Gadjah Mada, Department of Environmental Geography, \\ Faculty of Geography, Yogyakarta, Indonesia, e-mail: ssuprayogi@ugm.ac.id
}

Muh Aris MARFAI

Universitas Gadjah Mada, Department of Environmental Geography, Faculty of Geography, Yogyakarta, Indonesia, e-mail: arismarfai@ugm.ac.id

\section{Djati MARDIATNO}

Universitas Gadjah Mada, Department of Environmental Geography, Faculty of Geography, Yogyakarta, Indonesia, e-mail: djati.mardiatno@ugm.ac.id

\begin{abstract}
Citation: Naja, D.A., Suprayogi, S., Marfai, M.A., \& Mardiatno, D. (2021). A STUDY ON THE SOCIAL NETWORK ANALYSES OF DIVE CENTERS AND SUSTAINABLE TOURISM DEVELOPMENT IN PEMUTERAN BALI, INDONESIA. GeoJournal of Tourism and Geosites, 36(2spl), 603-615. https://doi.org/10.30892/gtg.362spl07-689
\end{abstract}

\begin{abstract}
The increasing interest of tourists over the last few decades in the Pemuteran Tourism Area has become a major challenge in its management and sustainability. The dive centers located in this area offer business services such as diving and snorkeling, which are the leading tourism activities in Pemuteran. These centers also experience various changes that are rel ated to business operations and conservation strategies. This study aims to (1) determine the characteristics of these centers in the Pemuteran marine tourism area, (2) analyze the network pattern between these centers in these areas, and (3) formulate a sustainable tourism developmental strategy. In addition, the study made use of a descriptive and qualitative research method. The data used was collected through semi-structured census interviews on the entire population of the dive centers in the Pemuteran marine tourism area. The results show that the collaboration network between dive centers in Pemuteran is a centralized collaboration. Furthermore, this collaboration occured in both operational and conservational activities. The nationality of the owner and the year in which the centers were established, are factors that influence the collaboration of dive centers in Pemuteran. Conclusively, optimizing the role of the government, and the involvement of local communities around Pemuteran is an important task needed in developing sustainable Pemuteran diving tourism.
\end{abstract}

Key words: Social network analysis, dive center, sustainable tourism, diving, SWOT, collaboration, coastal, Pemuteran Bali

$* * * * * *$

\section{INTRODUCTION}

Indonesia is one of the largest archipelagic countries in the world today, with 17,500 islands and a coastline of more than $80,000 \mathrm{~km}$ (Marfai, 2014). This coastline is said to be the second-longest in the world (Marfai et al., 2019). Geologically, ecologically and biologically, these coastlines have also proven to be very important in human life (Febriansyah et al., 2012). Furthermore, complex geomorphological processes are the factors that shape the uniqueness of coastal landscapes (Marfai et al., 2008). The complexity of these processes in coastal areas provides various benefits such as landscapes and marine resources, including fishery, mangroves, and coral reefs. In addition, coastal resources are one of the main economic sources of the Indonesian society (Marfai et al., 2019). The abundant resources in coastal areas are one of the reasons for increasing the potential for ecosystem services through marine tourism activities. The increase in public interest in nature tourism has recently encouraged the acceleration of various tourist activities, including ecotourism (Franco et al., 2019). In addition, the tourist sector in general also helps to support a region's local economy and provide added value to its coastal areas (Suprayogi et al., 2020; Lu et al., 2019; Mardiatno and Mutaqin, 2011; Dimmock and Musa, 2015).

However, although tourism provides benefits related to increased economic and employment opportunities, it also has major effects on the sustainability of the ecosystem (Sriartha and Giyarsih, 2015; Gerungan and Chia, 2020). The features of dynamic coastal areas and their sensitivity to anthropogenic activities require innovations that are oriented towards sustainable use. Therefore, achieving the goal of sustainability in coastal management and effective tourism activities requires the integration of both social and ecological systems of society (Dredge, 2006; Plummer and Fennel, 2009; Gerungan and Chia,

\footnotetext{
* Corresponding author
} 
2020; Marconi et al., 2020). Bali is one of the most popular tourist destinations in the local and international market. Its leading economic sector is tourism and it attracts a wide range of potential tourists from all over the world (Trialfhianty and Suadi, 2017). Most of the tourist centers located in this region are well known for their diversity in ecosystems and marine culture, which are the main source of attraction for both local and international tourists. Bali is a member of the Coral Triangle Island with the largest marine biodiversity in the world. In addition, the diversity of marine resources makes this region the center of tourism activities such as diving and snorkeling (Blicharska et al, 2019). Buleleng Regency is one of the autonomous regions in Bali with the longest coastline and it is located in the northern part of the Island. Furthermore, Pemuteran is one of the leading coral reef tourism destinations in this Regency (Windayati et al., 2020). Based on the number of tourists visiting the regency, there was also a significant increase in the number of tourists visiting Pemuteran (Figure 1). In 2005 a total of 56,523 people visited this regency in Bali. In 2019, it increased to 1,084,168 tourists, which included both local and international visitors. This presented major challenges for tourism development strategies as they need to be able to accommodate the changes caused by an increase in the number of tourists visiting these areas.

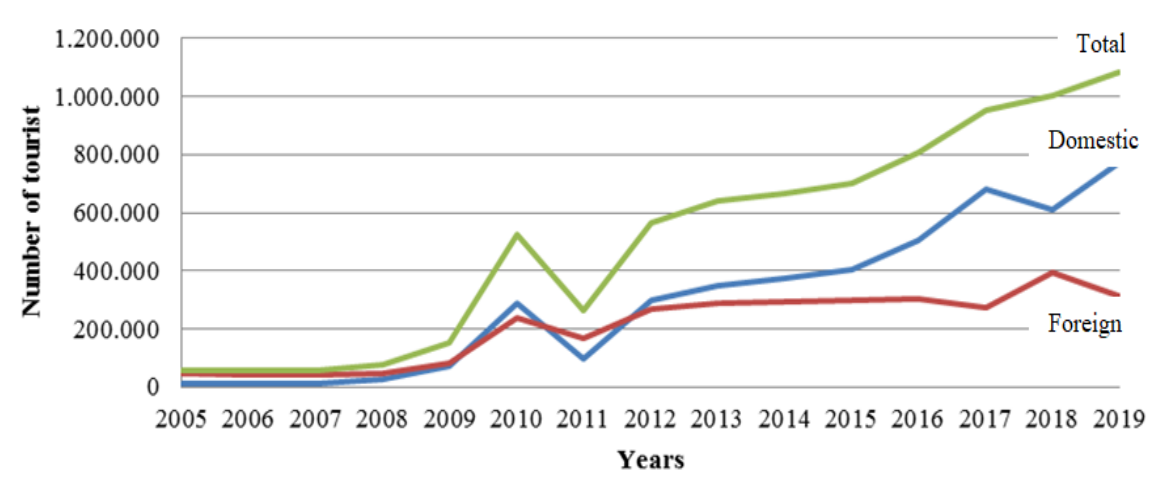

Figure 1. Number of tourist in Buleleng Regency 2005-2019 (Source: Buleleng in Figure, 2019)
The dive center is a marine tourism service business sector that provides services such as equipment rental and guides for underwater diving activities. The Pemuteran village is one of the leading diving tourism destinations in Buleleng Regency, with many of these centers existing as providers and facilitators of recreation. According to the Buleleng Tourism Office, these Pemuteran tourism centers have received many awards from various local and internationalawards, including

3 world-renowned awards such as the Equator Prize, PATA Gold, and G20 awards. In addition, in 2017, these Pemuteran tourism centers were nominated for the Indonesia Sustainable Tourism Award (ISTA) for their success in coral reef conservation through the application of Biorock technology and community participation. Furthermore, the biorock program succeeded in providing various benefits for both the surrounding community and underwater attractions by increasing marine biodiversity as well as diving and snorkeling activities respectively (Spalding et al., 2017; Jamison, 2009).

During, the developmental process, dive centers as one of the major commercial tourism service in Indonesia, experienced various changes related to service quality, business competition, and collaborative relationships while trying to increase the interest of local and foreign tourists in these places. Social networking among business owners in the tourism sector facilitates changes in governance in marine tourism development (Partelow and Nelson, 2018; Gerungan and Chia, 2020; Dimmock and Musa, 2015). The increasing tourist attraction for diving and snorkeling activities encourages sustainability challenges among business owners in developing Pemuteran diving tourism. An understanding of the characteristics and patterns of the diving service provider network and tourism environmental management may provide directions for future developments in tourism. Furthermore, research related to Social Network Analysis have been analyzed with various data and population strategies (Partelow and Nelson, 2018; Baggio et al., 2010).

A social network analysis approach can be used to assess the informal relationships between dive center owners that form the basis of collective action and environmental governance (Partelow and Nelson, 2018). In tourism, network science is an effective instrument for exploring the structure and performance of dive centers and, their complex tourism system (Scott et al., 2008; Baggio et al., 2010). In addition, social networking and collaboration between owners in tourist areas can be used to analyze various environmental problems (Bodin, 2017; Dimmock and Musa, 2015; Albrecht, 2013). This study aims to analyze the informal network between dive centers in relation to their business commitment and collective action to conserve the tourism environment and coral reefs. Commitment and collective action related to conservation are seen from the extent to which the dive center business adopts and implements environmental values into the company's operational standards and business behavior. In this study, the dive center is considered as one of the main factors needed in the success of environmental and coral reef conservation. This can be seen from their central role as a service provider and facilitator of tourism which is directly related to recreational diving activities. Furthermore, social, economic, and cultural influence are important aspects of tourism that need to be studied because of how they support the sustainability of the tourism system. They provide benefits that can be accepted by various parties, especially the surrounding community.

\section{METHODOLOGY}

The study was conducted in the marine tourism area of Pemuteran, Pemuteran Village. The village is one of the administrative areas in Gerokgak District, Buleleng Regency, which is located on the north coast of the island of Bali, Indonesia (Figure 2). Based on data acquisition, the data used in this study was divided into two, namely; primary and secondary data. The former was obtained directly from respondents in the form of owners, managers, and employees that were considered to know about the dive center. Its collection process was carried out through semi-structured interview techniques. The secondary data includes data obtained from sources outside the respondents that are needed to compile the research formulation and framework. 

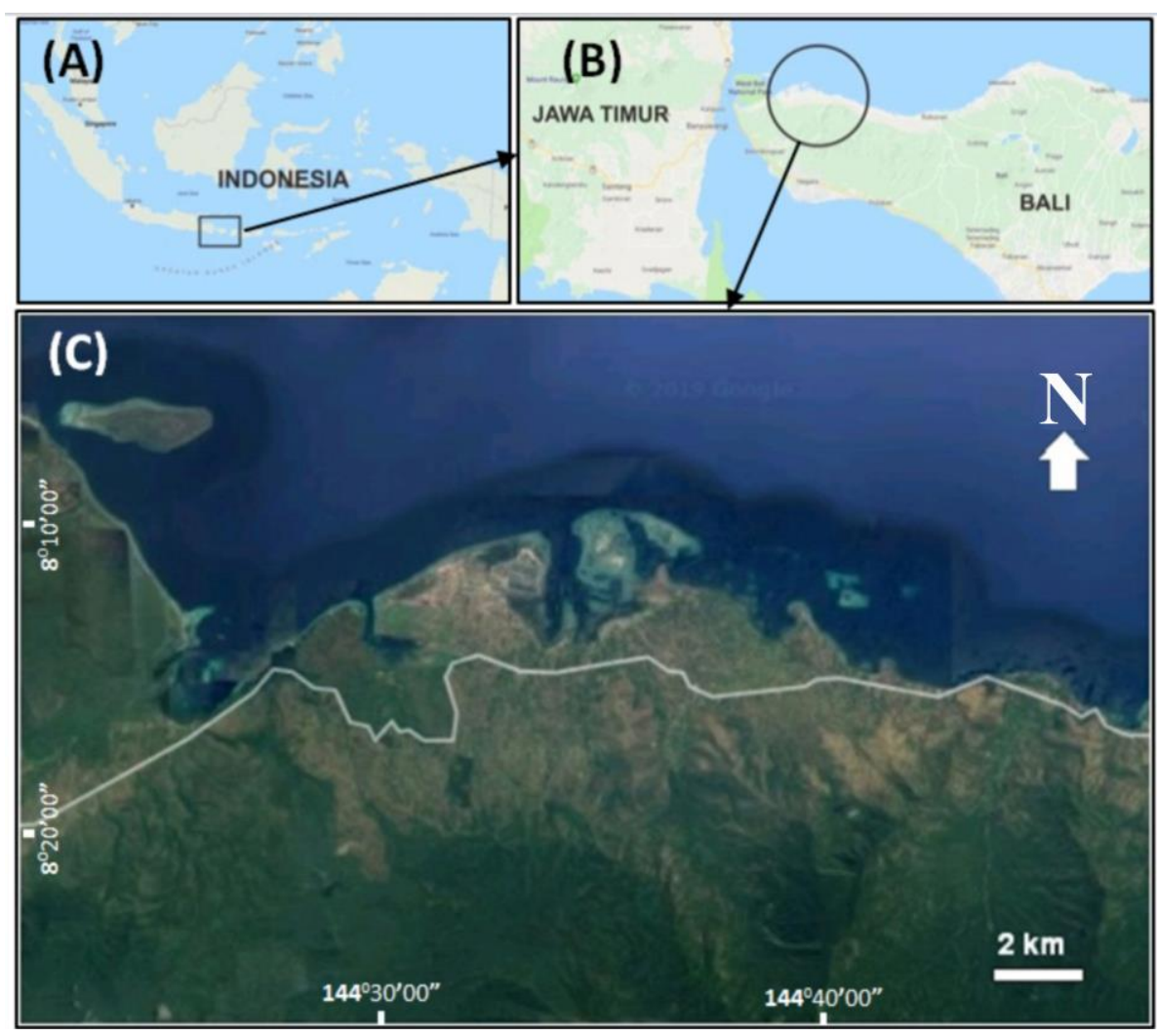

Figure 2. (A) Map of Indonesia and position of Bali Island, (B) Map of part of Bali island and study location, (C) Image of Pemuteran marine tourism study location (Source: Google Earth, 2019)
The population in this study were all the dive center tourism service providers in the Pemuteran tourism area, with a total of 30 dive centers. Data collection was carried out by means of a census at all these centers in the Pemuteran marine tourism area. Meanwhile, due to the pandemic, some of these centers did not operate fully while some were even closed permanently. This meant that in the research only 27 of these centers were interviewed. The pandemic had a major impact on tourism activities, forcing the author to make various alternative efforts in conducting this research. These efforts included online interviews, online questionnaires, and several interviews that were still being conducted at the research location using Covid-19 protocol. The data used in this study were collected through semi - structured and in - depth interviews with key informants including dive center owners or managers, leaders of local tourism organizations and local government officials. The interview aims to obtain information on the network or relationship between these centers and equipment management, exchange of employees, guides, and dive master certification. Furthermore, interviews with additional informants aimed to obtain in-depth information about the potential problems associated with future tourism development. Broadly speaking, the flow in this research is as in Figure 3. Several questions were asked to actor respondents, owners, managers, and staff that were considered to know the dive center business. The dive center data contained information such as year of establishment, owner's nationality, services provided, licenses, and number of employees. Furthermore, the data also made use of Partelow and Nelson's research (2018) to determine the orientation of the center's conservation commitments and network involvement. Questions about problems associated with tourism were adopted in the research of Dimopoulos et al. (2019) to determine the risk of impact of these problems on the diving tourism industry. Information related to dive center service standards and risk management for scuba diving tourism was obtained using the research of Setyoko and Kristiningrum (2019).

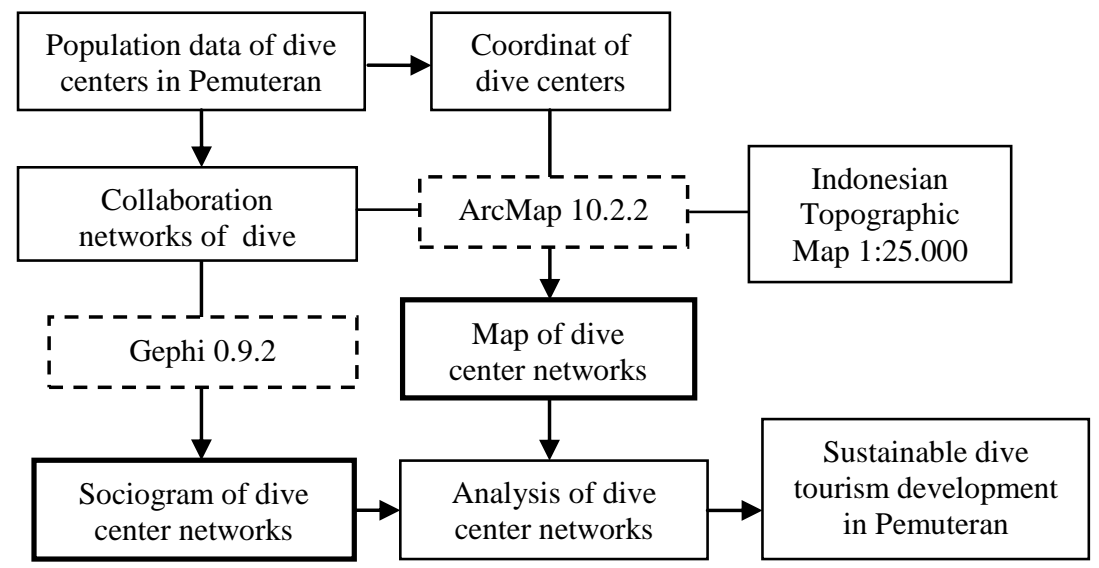

Figure 3. Flowchart of the research

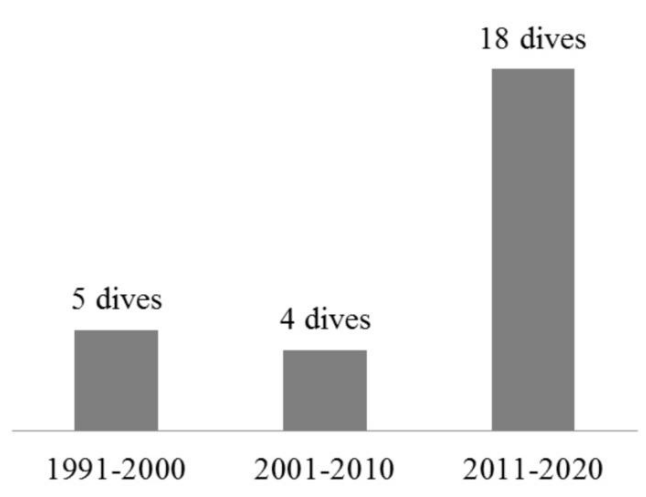

Figure 4. Number of dive centers established per 10 years in the last three decades (Source: Respondent data collection, 2019)

Furthermore, network analysis was performed digitally using Gephi software. The results of the analysisillustrated the network pattern regardless of the geographical location of the dive center unit. In Partelow and Nelson's (2018) research, information on the distance between 2 centers less than 50 meters of each other, were defined as neighbors and displayed in certain colors. Meanwhile, this study also displayed the network pattern by plotting the geographic al coordinates of each center onto a map. Respondents were also asked to convey various internal and external problems faced by dive centers, as 
well as the development of Pemuteran marine tourism in general. This information is intended to provide alternative solutions to the various social, economic, political, cultural, and environmental problems and challenges experienced by these centers and tourism developmental processes. Consequently, SWOT analysis is a process of systematically identifying variations in factors considered in a research, so as to formulate useful strategies (Kurniawan et al., 2020; Cahyadi et al., 2018). It (SWOT-Strength, Weakness, Opportunity, Threat) was conducted based on information in the field, including the perspective of respondents that are considered important people in leading tourism activities (diving) in Pemuteran. Furthermore, the findings or facts from various additional informants, as well as facts from literature studies were used as information needed in the formulation of alternative solutions to problems encountered in Pemuteran marine tourism.

Table 1. List of Dive Centers in Pemuteran Tourism Area, Bali

\begin{tabular}{|c|c|c|c|c|c|c|}
\hline Dive Center & Year & Nationality & Number of staff & Certification & Service & Dive category \\
\hline Dive 1 & 1991 & Italy & $11-20$ & PADI & diving equipment, guides & Dive shop \\
\hline Dive 2 & 1995 & Indonesia & $6-10$ & PADI & diving equipment, guides, rent ship & Dive shop \\
\hline Dive 3 & 1998 & Slovenia & $6-10$ & PADI & diving equipment, guides & Dive shop \\
\hline Dive 4 & 2000 & Australia & $>20$ & PADI & diving equipment, homestay & Dive resort \\
\hline Dive 5 & 2000 & Indonesia & $6-10$ & PADI & $\begin{array}{l}\text { diving equipment, guides, homestay, } \\
\text { transportation,rent ship,restaurant }\end{array}$ & Dive resort \\
\hline Dive 6 & 2004 & German & $11-20$ & PADI, SSI & diving equipment, guides, homestay, rent ship & Dive resort \\
\hline Dive 7 & 2007 & Switzerland & $6-10$ & PADI & $\begin{array}{l}\text { diving equipment, guides, homestay, } \\
\text { transportation, }\end{array}$ & Dive resort \\
\hline Dive 8 & 2007 & Indonesia & $1-5$ & PADI & diving equipment, guides, homestay & Dive resort \\
\hline Dive 9 & 2008 & French & $1-5$ & SSI, SDI & diving equipment, guides & Dive shop \\
\hline Dive 10 & 2011 & Indonesia & $6-10$ & PADI & diving equipment, guides, homestay & Dive resort \\
\hline Dive 11 & 2012 & French & $6-10$ & SSI & diving equipment, guides & Dive shop \\
\hline Dive 12 & 2012 & Indonesia & $>20$ & PADI, SSI, RAID & diving equipment, guides, homestay, rent ship & Dive resort \\
\hline Dive 13 & 2012 & Indonesia & $6-10$ & SSI & diving equipment, guides & Dive shop \\
\hline Dive 14 & 2012 & French & $11-20$ & PADI & diving equipment, guides, homestay, rent ship & Dive resort \\
\hline Dive 15 & 2013 & Indonesia & $1-5$ & PADI & diving equipment, guides & Dive shop \\
\hline Dive 16 & 2014 & Indonesia & $6-10$ & SSI & diving equipment, guides, homestay, restaurant & Dive resort \\
\hline Dive 17 & 2014 & Indonesia & $11-20$ & PADI & diving equipment, guides, homestay, restaurant & Dive resort \\
\hline Dive 18 & 2015 & America & $11-20$ & PADI & diving equipment, guides, homestay,rent ship & Dive resort \\
\hline Dive 19 & 2015 & Indonesia & $>20$ & PADI & diving equipment, guides, homestay, restaurant & Dive resort \\
\hline Dive 20 & 2015 & Canada & $1-5$ & PADI & diving equipment, guides & Dive shop \\
\hline Dive 21 & 2016 & Indonesia & $1-5$ & PADI & diving equipment, guides & Dive shop \\
\hline Dive 22 & 2016 & Indonesia & $6-10$ & RAID & diving equipment, guides,rent ship & Dive shop \\
\hline Dive 23 & 2017 & Indonesia & $1-5$ & PADI & diving equipment, guides & Dive shop \\
\hline Dive 24 & 2018 & Indonesia & $1-5$ & PADI & diving equipment, guides & Dive shop \\
\hline Dive 25 & 2019 & Portugal & $1-5$ & SSI & diving equipment, guides, homestay, rent ship, & Dive resort \\
\hline Dive 26 & 2019 & Indonesia & $6-10$ & PADI & diving equipment, guides, homestay & Dive resort \\
\hline Dive 27 & 2019 & Indonesia & $6-10$ & PADI & diving equipment, guides, homestay, transportation & Dive resort \\
\hline
\end{tabular}

\section{RESULT}

\section{Identified Dive Center Characteristics}

The results of the primary data are seen in Table 1. Based on the data and information obtained, the existence of a dive center as a diving tourism service provider started from 1980-1990 in Pemuteran. The first center recorded in the study has been operating for about 30 years. During this period, variouscenters emerged along with the increased interest of tourists in diving activities. A total of 18 dive centers from this study population have been established in the last decade (Figure 4).

The dive centers in Pemuteran are mostly owned by indigenes of the community, with only $40 \%$ having foreign owners. The foreign centers may have owners from America, Germany, Italy, Australia, Switzerland, Portugal, Slovenia, Canada and France. In addition, the dive centers operate businesses that only provide diving tourism services such as a dive shop and a homestay service known as a dive resort. However, several other services such as restaurants, transportation, souvenirs and other tourists needs, are provided by some of the diving centers. Consequently, the number of staff available can describe the scale of the business being run by the owner of the dive center. Most of the centers in Pemuteran run businesses that are mostly dominated by middle to small scale business owners with staffs in groups of 1-5 and 6-10 respectively.

Diving is an activity that requires skill, expertise, and the ability for you to be able to dive underwater without the availability of air needed to breathe. When carrying out an activity such as diving, divers are required to have a license (Ong and Musa, 2011), and are expected to know the rules that govern safe underwater practices. These licenses are issued by diving agencies that are recognized internationally, and each organization has different methods and levels of training and expertise respectively. In general, dive center business owners that are diving activists usually have a license issued by a recognized institution. The majority of these centers in Pemuteran chose PADI as their diving master's license (Figure 5).

In carrying out recreational diving activities, various diving equipment instruments are needed to be able to dive under water. Basic diving equipment such as a wetsuit, fint, diving mask, buoyancy control device, weight system, and scuba tank, are owned by all dive centers (Figure 6). Some Dive centers in Pemuteran already have basic diving equipment for rent to their 
businesses. To reach a dive site that is far from the mainland, divers need a ship as a means of sea transportation. Boats are not owned by all dive centers in Pemuteran, only around 52\% of dive centers own ships. A dive center that does not have a boat can borrow or rent another dive center that has one, sometimes they also share boats to meet customer needs.

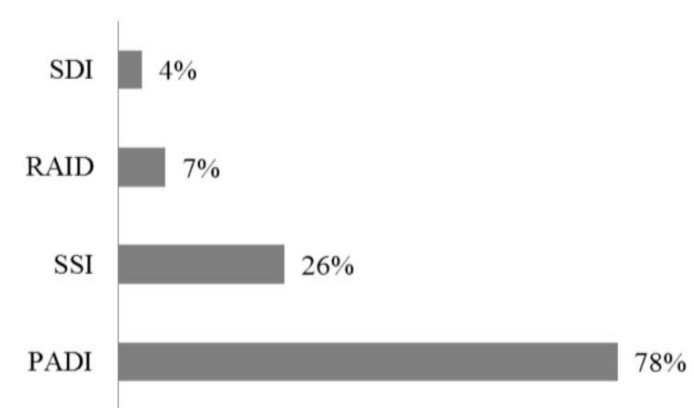

Figure 5. Diving license agencies used by dive centers in Pemuteran (Source: Respondent data collection, 2019)

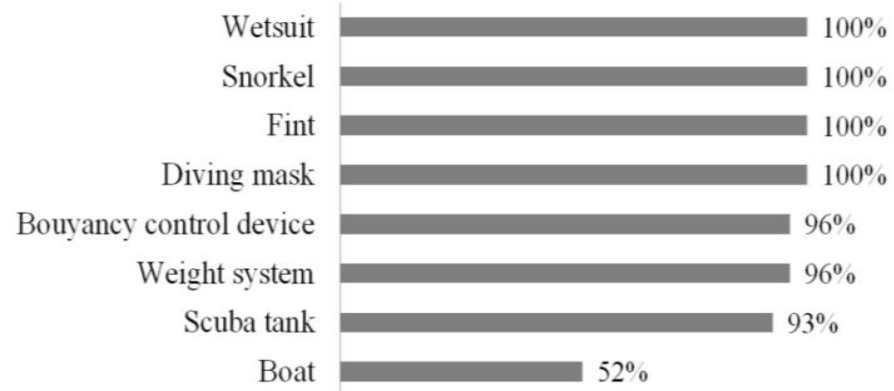

Figure 6. Availability of diving equipment at dive centers in Pemuteran Pemuteran (Source: Respondent data collection, 2019)

\section{Dive Center Network Analysis}

Social network analysis can be used to describe the network structure needed in sustainable tourism development (Nguyen et al., 2019; Otte and Rousseau, 2002). Network science methods can provide benefits in deepening knowledge about the entire system (Baggio et al., 2010). The basic idea of network science is that social structures influence decisions, individual beliefs and behavior (Scott, 2000; Garcia-Hernandez, 2020). In a study conducted by Trialfhianty and Suadi (2017), it is stated that the level of interaction will affect the way of thinking that it is important to restore coral reefs in Pemuteran.

The analysis of social networks among dive center operators is shown in Figure 7. It emphasizes more on the pattern of relationship rather than concentrating on individual behavior or the unity of the network system (Wasserman \& Galaskiewicz, 1994). The network pattern diagram shows the cooperative relationship in the operation and provision of diving services. The dive network is represented by the depiction of elements in the form of points and the relationship in the form of a line connecting the points (Baggio et al., 2010). The difference in stain color represents the nationality of the owner and the size of the stain represents the degree of centrality based on the number of relationships. The stain label is represented by the year the dive center was established. Based on the characteristics of the relationship between dive center business owners in Pemuteran, the level of interaction between owners can be classified based on the network structure used by Bodin (2017) in his research. The network structure as stated by Bodin is an open triangular classification system. This meant that two friends connected by a node in the triangle may not necessarily be connected to each other. The entire trend in his classification system can be seen as a whole based on the extent in which members of the triangle related with each other. However, in some partial relationships among members, there are also network structures that are almost triangular.

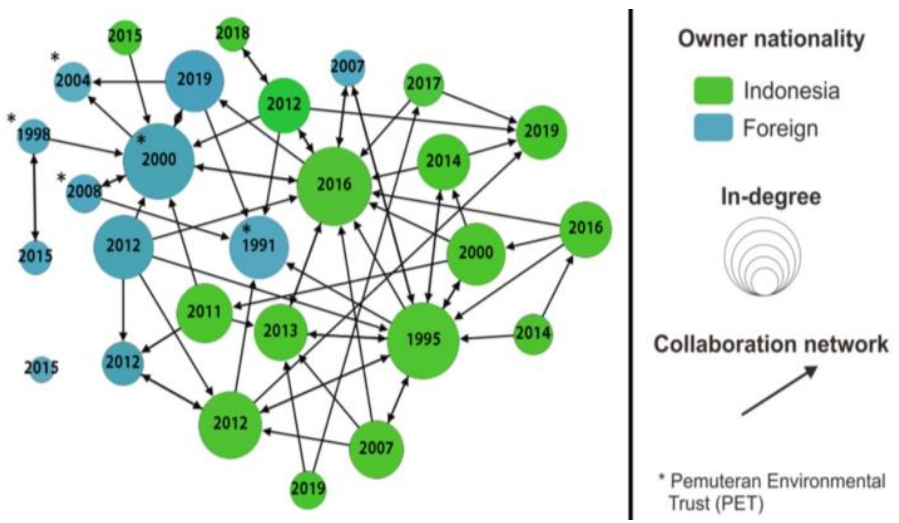

Figure 7. Sociogram of dive center networks in Pemuteran

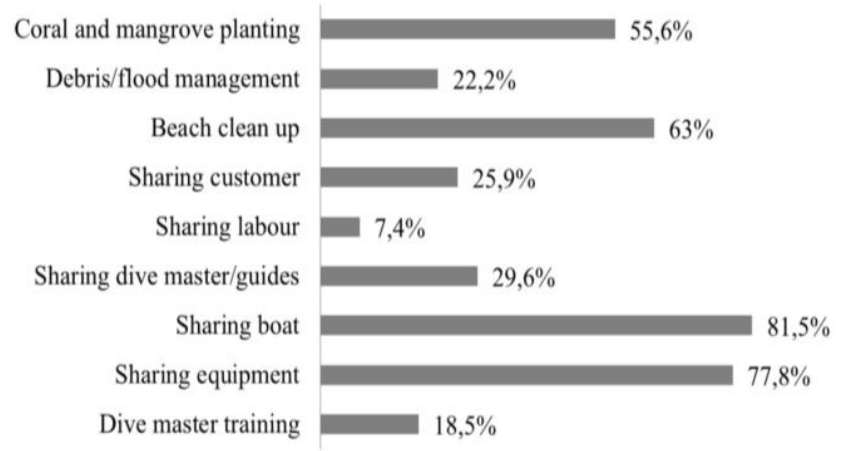

Figure 8 . Kinds of collaborative activities between dive centers in Pemuteran Pemuteran (Source: Respondent data collection, 2019)

Furthermore, trust and social capabilities are two main driving factors for collaborative relationships among business owners in Pemuteran (Partelow and Nelson, 2018). Moreover, the social network that exists between dive center owners should be able to accommodate the change resulting from marine management and conservation, as well as maintaining the sustainability of tourism (Dimmock and Musa, 2015). Baggio et al. (2020) argued that tourism is a complex dynamic system that is moving further away from a static equilibrium. The increase in the number of dive center business operators has also created social changes, particularly in relation to price competition and service quality. In addition, the establishment of a new business center has a way of increasing price competition in the business sector of any unstable economy (Gerungan and Chia, 2020). Although price standardization has been achieved, and according to several respondents, divers admitted that there are still centers in Pemuteran that do not comply with the agreed price tag. Even though an agreement has been made, there should still be laid down rules and regulations that support the obedience of this agreement as well as guarantees punishment for its violators. Dive center businesses in Pemuteran are quite good at 
supporting the protection of the tourism environment and the conservation of marine life. Acollective identity as fellow dive service providers in Pemuteran tourism creates the collective awareness needed in protecting the shared marine space.

A sense of shared ownership of the tourism environment and marine life as a source of income leads to the establishment of common goals related to the sustainability of tourism in Pemuteran. Furthermore, increased concern for illegal fishing which results in degradation of coral reefs is a motivation for coral reef restoration through the biorock technique. Based on the dive center network in Pemuteran, it can be observed that there is every tendency for the network to collaborate with certain characteristics in common. Collaborative tendencies among dive center owners are connected and grouped based on the nationality of the owners. Moreover, in the network system there are central actors that connect the dive center sub-network. Owners that only interact with sub-groups of people with a certain homogeneity of characteristics find it easier to develop their own sub-culture, while owners that are connected in groups with a variety of backgrounds, roles, and resources benefit more in deepening the complexity of the problem and having more alternatives (Bodin, 2017). However, the collaborative relationship between local and non-local businesses is still quite good. It's just that small collaborative dive centers are only connected to other centers with the same national classification.

Partelow and Nelson (2018) argue that cultural heterogeneity is a factor inhibiting the possibility of collaboration due to increased transaction costs. The collaborative relationship between dive centers in Pemuteran is more intensive on operational relationships such as sharing boats and diving equipment. $81 \%$ of dive centers do collaborative activities in the form of sharing boats and $77.8 \%$ share diving equipment with other dive centers. $55.6 \%$ of the conservation cooperation in the form of planting coral reefs and $63 \%$ stated that doing beach clean-up activities as a collective dive center activity (Figure 8). Cooperation in terms of conservation and environmental management shows that it is less frequent than operational activities. The Pemuteran Environmental Trust (PET) was founded in 2009 after a lengthy debate about how conservation efforts could be made to offset exploitation of the tourism environment. It consists of dive business owners in Pemuteran that have the intention of contributing to environmental sustainability, realization of marine conservation, coastal management, and community services through various skill enhancement. Through this program, dive centers that are a part of PET facilitates various parties that wish to contribute to the sustainability of Pemuteran tourism.

This program accommodates a minimum funding contribution of IDR 25,000 per tourist, which is added to the bill for tourism services such as diving and snorkeling. Furthermore, it also facilitates parties that intend to help promote the project and make donations. This project is a form of awareness for dive center entrepreneurs to secure the interests of the next generation in enjoying tourism in line with the development of its complexity. Its members consist of 5 dive centers, all of which are non-local owned and were established from 1991-2008.

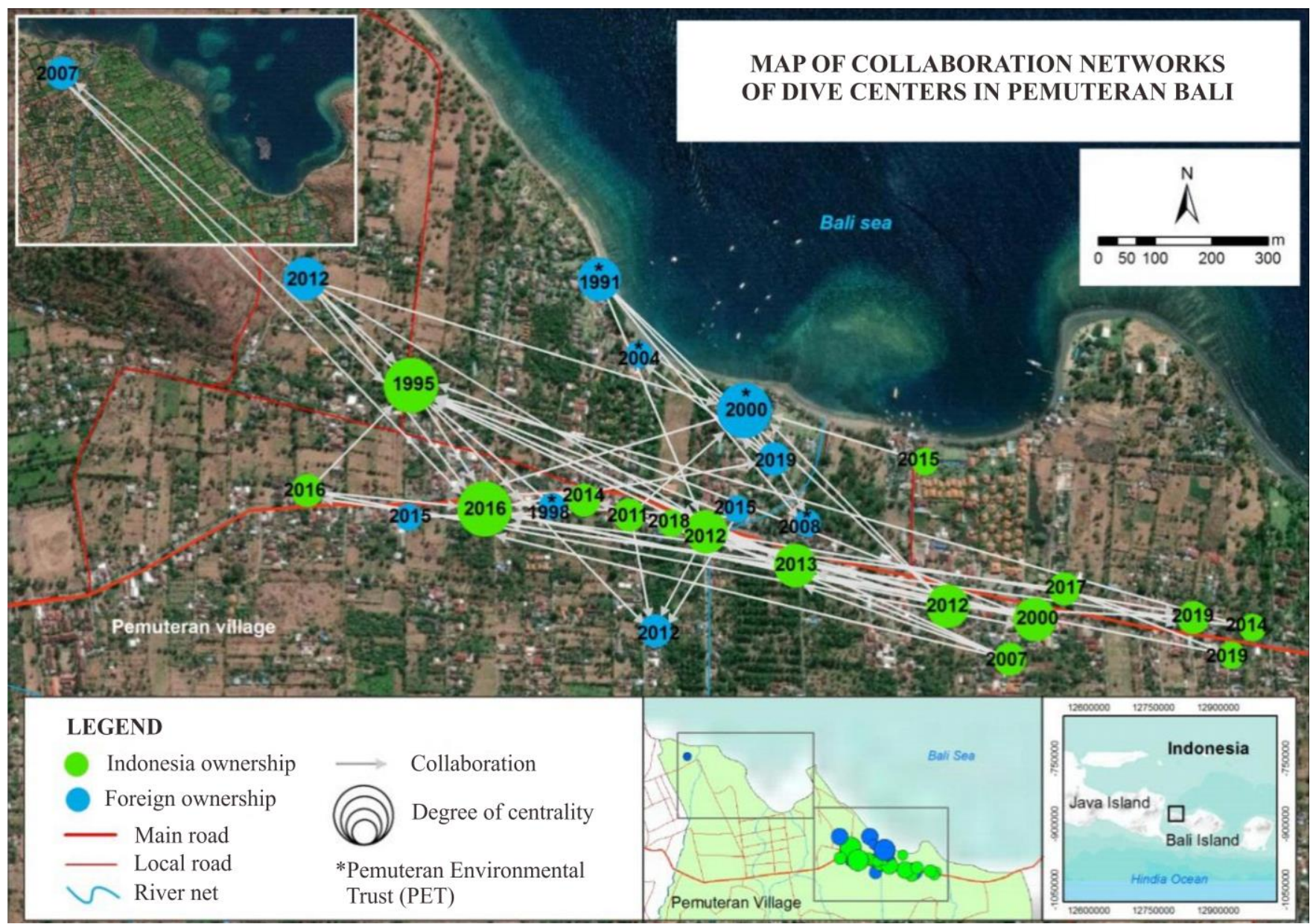

Figure 9. Dive Center Collaboration Network Map in Pemuteran Tourism Area, Bali (Source: ESRI USGS, UTM WGS 1984 50S) 


\section{Dive Network Spatial Analysis}

In Partelow and Nelson's (2018) study, the dive network analysis was only carried out non-spatially without considering the distribution of the center's location. Furthermore, the depiction of the collaborative relationship between centers that are close to each other is represented by a certain color. This study aims to examine the relationship pattern of these business owner's collaboration in spatial terms, and how the role of the spatial aspect of their collaboration affects their network pattern. Figure 9 shows the distribution of the dive center consisting of a dive shop and dive resort in the Pemuteran tourism area. The study location is in the northern coastal area of Bali which includes the administrative boundary of the Pemuteran Village. The dive center as a diving tourism service provider shows a linear pattern distribution following the main road that connects between administrative areas on the north coast of Bali and the center of the Bali Province. The main road's access dominantly controls the distribution in which these business owners establish themselves. This indicates that for divers, proximity to the sea area is not as important as the ease with which customers find these centers and then choose the dive services offered.

Centers with dive shops that only provide diving equipment rental services and guides are more commonly found along the main road. Meanwhile, in locations far from the main road, there are more dive resorts with lodging amenities. This shows that there is an increased need for centers with dive resorts. The resorts provide a beautiful scenery for customers and improves their level of comfort drastically. The proximity of the dive centers in the Partelow and Nelson (2018) study is represented by level of neighboring collaboration, which also represents the distance between two of these centers of being not more than 50 meters apart. Collaboration based on distance can illustrate how effective and intensive a partnership can be. Cehan et al. (2020) guessed that geographic proximity stimulates social closeness because short spatial distances support social interactions and trust building. In this study, the spatial aspect was considered to not really be a major influence in the behavior of operational and conservational collaboration among dive center owners. Furthermore, closeness and proximity among dive centers is not significant factor that needs to be considered when establishing collaborative relationships amongst owners. Actors with larger collaborative networks tend to partner with other dive centers because of the extent of their level of operation and ownership of the ship. Moreover, another significant factor that needs to be considered in a collaborative relationship in tourism operations is ship ownership. Some divers often choose to share the boat if they get customers who want to visit Menjangan Island and its diving sites. This can reduce rental costs for fellow divers in question.

Another finding from the results of the dive distribution mapping shows that the distribution of dive centers with local ownership is more dominant in areas with access to the main road. It can also illustrate easier access to plots of land for residents to build their business buildings. Long-standing land ownership, both personal assets and inheritance from their ancestors, as well as ease in negotiations with close cultural ties between residents, can be the supporting background for this condition. Conversely, the dive centers with non-local ownership are spread out over lands that are far from the main road. Most of them choose to establish their business in places north of the main road but close to the sea. The need of foreign nationals to have a place of business in Indonesia goes through a variety of licensing processes and more complicated negotiations, both from the ease of connection and the negotiated price of land.

\section{Network of Dive Centers in Sustainable Pemuteran Tourism}

The business owners' perceptions of the survey questionnaire statements related to environmental issues, conservation, and network collaboration are shown in Table 2. The success of the coral reef conservation project in Pemuteran is influenced by the community's view on the matter (Trialfhianty and Suadi, 2017). Community can be formed when the population interacts to influence one another to form a socio-culture (Tonnies, 1999). On a smaller scale, the number of dive business owners that had interactions with members of the community represents the socio-cultural group of tourism service providers. They related to community perceptions, operational agreements, and conservation commitments in tourism activities.

Table 2. Divers' perceptions of conservation and collaboration networks in Pemuteran Tourism

\begin{tabular}{|c|c|c|c|c|}
\hline No & Statements & Disagree & Neutral & Agree \\
\hline 1 & The issues related to coastal environmental conservation/restoration of coral reefs in Pemuteran have been well managed & $26 \%$ & $15 \%$ & $59 \%$ \\
\hline 2 & The issue of shared waste and the recycling process in Pemuteran has been well managed & $44 \%$ & $22 \%$ & $33 \%$ \\
\hline 3 & Damage to reefs will occur frequently in the future & $7 \%$ & $15 \%$ & $78 \%$ \\
\hline 4 & There is support from outside donors related to environmental/reef conservation & $11 \%$ & $15 \%$ & $74 \%$ \\
\hline 5 & There are regular fees for environmental conservation in Pemuteran & $15 \%$ & $52 \%$ & $33 \%$ \\
\hline 6 & Many people catch fish & $19 \%$ & $30 \%$ & $52 \%$ \\
\hline 7 & Destructive fishing & $52 \%$ & $33 \%$ & $15 \%$ \\
\hline 8 & There is a tour guide service at this dive center & - & $4 \%$ & $96 \%$ \\
\hline 9 & There is a briefing/appeal for tourists before diving in a safe and environmentally friendly manner & - & $7 \%$ & $93 \%$ \\
\hline 10 & Collaboration with other businesses is easy on Pemuteran tourism & $26 \%$ & $26 \%$ & $48 \%$ \\
\hline 11 & More cooperation between dive centers is needed & $19 \%$ & $30 \%$ & $52 \%$ \\
\hline 12 & The more businesses on this tour the more difficult it is to cooperate and solve problems & $26 \%$ & $19 \%$ & $56 \%$ \\
\hline 13 & There is maintained local wisdom, such as traditional and religious ceremonies in Pemuteran tourism & - & - & $100 \%$ \\
\hline 14 & There is a cultural festival as an effort to promote Pemuteran tourism & $4 \%$ & $4 \%$ & $93 \%$ \\
\hline 15 & Willing to help if there is a cultural festival in the context of promotion & - & $11 \%$ & $89 \%$ \\
\hline
\end{tabular}

Based on respondents' statements, 59\% of these individuals agreed that the issue of coastal environmental conservation and coral reef restoration in Pemuteran has been well managed. Meanwhile, only 33\% of respondents agreed that the waste was managed properly. Furthermore, $78 \%$ stated that damage to coral reefs will occur frequently in the future. In addition, 
restoration efforts are not the only way to stop the degradation of coral reefs in waters. Preventive solutions are still needed before damage occurs through the management of domestic waste on land. Additionally, issues related to illegal fishing are still a problem in reef conservation. Destructive fishing practices can cause the decline in productivity of coral reef ecosystems (Richmond, 2011; Dimopoulos et al., 2019). Recreational diving is known to have direct and indirect impacts on coral reef habitats (Giglio et al., 2020; Palma et al., 2019; Chung et al., 2013; Dearden et al., 2007). The direct impact of diving tourism activities includes increased sedimentation, damage, and diseases which cause a decrease in coral abundance (Lyons et al., 2015). The indirect impacts are related to changes in land use which result in waste disposal in coral reef habitats (Hughes et al., 2017; Guzner et al., 2010). The diver's perception shows that almost all of them emphasize that damage to coral reefs can disrupt diving activities (Table 3). Meanwhile, the statement that diving has an impact on coral reef stability originates from different perceptions. Most of the dive center operators agree that diving will not have a significant impact on coral reefs if it is carried out in a safe and friendly marine environment (Ha et al., 2020; Marconi et al., 2020).

Table 3. Dive business operators' perceptions regarding the impact factors of diving tourism in Pemuteran

\begin{tabular}{|c|c|c|c|c|}
\hline No & Statements & Disagree & Neutral & Agree \\
\hline \multirow[t]{2}{*}{1} & The damage to the reef had an impact on the dive business & - & $4 \%$ & $96 \%$ \\
\hline & The diving activities have an impact on coral reefs & $37 \%$ & $30 \%$ & $33 \%$ \\
\hline 2 & The price increases have an impact on the dive business & - & $15 \%$ & $85 \%$ \\
\hline 3 & The decreased income and purchasing power had an impact on the dive business & $11 \%$ & - & $89 \%$ \\
\hline 4 & The increase in fuel has an impact on the dive business & $7 \%$ & $15 \%$ & $78 \%$ \\
\hline \multirow[t]{2}{*}{5} & The ease of access has an impact on the high number of dive tourism visitors & $4 \%$ & $4 \%$ & $93 \%$ \\
\hline & It is easy for foreign tourists to go to Pemuteran tourist sites & $44 \%$ & $11 \%$ & $44 \%$ \\
\hline \multirow[t]{2}{*}{6} & Multinational outbreaks have an impact on dive tourism visits & - & - & $100 \%$ \\
\hline & Pemuteran tourism is safe from the pandemic (Covid-19) & $15 \%$ & $26 \%$ & $59 \%$ \\
\hline \multirow[t]{2}{*}{7} & The social crime rate has an impact on diving activities & $15 \%$ & $7 \%$ & $78 \%$ \\
\hline & Pemuteran tourism is safe from social crime & $15 \%$ & $7 \%$ & $78 \%$ \\
\hline 8 & Political stability has an impact on dive tourism activities & $11 \%$ & $11 \%$ & $78 \%$ \\
\hline 9 & Strict visa regulations impact the dive business & $4 \%$ & $22 \%$ & $74 \%$ \\
\hline 10 & Travel restrictions for security reasons (disaster, terrorism have an impact on diving) & $7 \%$ & - & $93 \%$ \\
\hline
\end{tabular}

Table 4. Minimum standard of dive center business services in Pemuteran

\begin{tabular}{|c|c|c|c|c|}
\hline No & Statement & Disagree & Neutral & Agree \\
\hline 1 & Dive guides have the knowledge and track records of dive sites and locations & - & $7 \%$ & $93 \%$ \\
\hline 2 & Dive guides have the capability to handle tourist safety, including in emergencies & $3 \%$ & $4 \%$ & $93 \%$ \\
\hline 3 & Dive guides have sessions to brief on procedures during the dive & $4 \%$ & - & $96 \%$ \\
\hline 4 & The dive guide has a license from a reputable national/international training institute & $4 \%$ & - & $96 \%$ \\
\hline 5 & Dive guides are licensed as dive instructors & $7 \%$ & $11 \%$ & $82 \%$ \\
\hline 6 & $\begin{array}{l}\text { There is proper equipment: regulator, buoyancy control device (BCD), diving mask, } \\
\text { fins, scuba tanks, wetsuit, scuba weight system, and air pipes }\end{array}$ & - & $4 \%$ & $96 \%$ \\
\hline 7 & Having documentary equipment for using diving equipment & - & $15 \%$ & $85 \%$ \\
\hline 8 & $\begin{array}{l}\text { Having the necessary supporting facilities for diving: communication equipment, } \\
\text { surface markers, ship flag buoys, first aid kits, and oxygen according to standard }\end{array}$ & $4 \%$ & - & $96 \%$ \\
\hline 9 & Having a diving guidance competency training program & $4 \%$ & $11 \%$ & $85 \%$ \\
\hline 10 & Having a health assessment program for diving customers & $4 \%$ & $15 \%$ & $81 \%$ \\
\hline 11 & Having an environmentally friendly dive monitoring program & - & $4 \%$ & $96 \%$ \\
\hline 12 & Following the rules of conservation and observation of marine life & $4 \%$ & - & $96 \%$ \\
\hline
\end{tabular}

They also agree that access to these centers is a factor that has a significant impact on tourist visits. Meanwhile, the statement regarding the ease of access of Pemuteran tourist sites shows the different perceptions of the dive business operators. Responses related to how easy it is to access these tourist sites are influenced by differences in perceptions and viewing accessibility. The first perception is that the ease of access to these tourist sites in Pemuteran is partly because of the good road infrastructures and main roads leading to these places. The second perception is that foreign tourists would find it difficult to reach these dive centers in Pemuteran because of the long distance between the airport and these centers. The minimum standard criteria for service in the dive industry are aimed at minimizing risks in diving activities. It is based on several factors, including the workplace, humans, and the natural environment (Setyoko and Kristiningrum, 2019). These three factors are described in several criteria as in Table 4. Based on the collection of information regarding the minimum standard of dive center services in Pemuteran, it is safe to assume that these centers meet a certain amount of these standards, even though it is not optimal in some criteria. Furthermore, some dive center owners in Pemuteran do not have licenses to own these sites, neither do they have the right to hire diving instructors in these places. However, in terms of providing basic diving equipment that is decent and meets certain standards, $96 \%$ of respondents meet this requirements. Meanwhile, the availably of other materials, such as documents on the use of tools and health assessment programs, has not been fulfilled by several owners of these centers.

\section{Sustainable Pemuteran Dive Tourism Development Strategy}

The respondents were also asked to provide information regarding potential and strategic issues related to tourism development in general and diving tourism activities specifically. Potentials and problems associated with tourism include four 
SWOT parameters, namely Strength, Weakness, Opportunity, and Threats (Zheng et al., 2020). The SWOT approach is widely used in strategic planning (Liu et al., 2019). Furthermore, most research find it necessary to use dive business owners as factors that are directly related to diving tourism activities in Pemuteran. Based on the collection of this information, the research summarizes and identifies the main factors (internal and external) in Pemuteran tourism development (Table 5; Table 6; Table 7).

Table 5. Identification of SWOT factors

\begin{tabular}{|l|l|r|l|}
\hline \multicolumn{2}{|c|}{ Strengths (S) } & \multicolumn{2}{c|}{ Weaknesses (W) } \\
\hline S1 & The charm of Menjangan Island & W1 & Low involvement of local communities \\
\hline S2 & Underwater beauty and varied dive sites & W2 & Lack of community skills in supporting tourism \\
\hline S3 & Beautiful rural conditions & W3 & Lack of waste management \\
\hline \multirow{2}{*}{ S4 } & \multirow{2}{*}{ The Biorock conservation project exists } & W4 & Illegal fishing activities \\
\cline { 3 - 5 } & & W5 & Domestic waste problem \\
\hline \multicolumn{2}{|c|}{ Opportunities $(\mathbf{O})$} & & \multicolumn{2}{|c|}{ Threats (T) } \\
\hline O1 & Tourists have increased over the last decade & T1 & There are more and more illegal dive businesses \\
\hline \multirow{2}{*}{ O2 } & \multirow{2}{*}{ An annual cultural festival as a promotional effort } & T2 & More and more dive staff are not licensed \\
\cline { 3 - 5 } & & T3 & Price competition is unhealthy \\
\cline { 3 - 5 } & T4 & Impact of a pandemic \\
\hline
\end{tabular}

Table 6. Matrix IFAS

\begin{tabular}{|l|l|l|l|l|l|}
\hline No. $\quad$ Internal Factors & Significant value & Weight & Rating & Score & Total \\
\hline Strengths (S) & & & & & \\
\hline 1. The charm of Menjangan Island & 2.280 & 0.251 & 3.67 & 0.920 & \\
\hline 2. Underwater beauty and varied dive sites & 0.997 & 0.110 & 3.33 & 0.365 & \multirow{2}{*}{1.803} \\
\hline 3. Beautiful rural conditions & 0.997 & 0.110 & 3.4 & 0.373 & \\
\hline 4. The Biorock conservation project exists & 0.435 & 0.048 & 3 & 0.144 & \\
\hline Weaknesses (W) & & & & & \\
\hline 1. Low involvement of local communities & 1.732 & 0.191 & 3.22 & 0.614 & \multirow{2}{*}{1.509} \\
\hline 2. Lack of community skills in supporting tourism & 0.758 & 0.083 & 2.74 & 0.228 \\
\hline 3. Domestic waste problem management & 1.316 & 0.145 & 3.3 & 0.478 \\
\hline 4. Illegal fishing activities & 0.574 & 0.063 & 3 & 0.189 & \\
\hline Total & 9.090 & 1 & & & 0.293 \\
\hline
\end{tabular}

Table 7. Matrix EFAS

\begin{tabular}{|c|c|c|c|c|c|c|}
\hline No. & External Factors & Significant value & Weight & Rating & Score & Total \\
\hline Opportunities (O) & & & & & \\
\hline 1. & Tourists have increased over the last decade & 1.732 & 0.244 & 3.56 & 0.870 & 1.145 \\
\hline 2. & An annual cultural festival as a promotional effort & 0.574 & 0.081 & 3.4 & 0.275 & \\
\hline$\quad$ Threats (T) & & & & & \\
\hline 1. & There are more and more illegal dive businesses & 1.313 & 0.185 & 2.96 & 0.548 & 2.258 \\
\hline 2. & More and more dive staff are not licensed & 0.435 & 0.061 & 2.81 & 0.173 & \\
\hline 3. & Price competition is unhealthy & 0.756 & 0.107 & 3.26 & 0.348 & \\
\hline 4. & Impact of a pandemic & 2.280 & 0.322 & 3.7 & 1.190 & \\
\hline \multicolumn{2}{r|}{ Total } & 7.090 & 1 & & & -1.113 \\
\hline
\end{tabular}

Table 8. SWOT matrix formulation of sustainable dive tourism development strategies

\begin{tabular}{|l|l|l|l|l|}
\hline Matriks SWOT & \multicolumn{2}{|c|}{ Strength (S) } & \multicolumn{2}{|c|}{ Weakness (W) } \\
\hline Opportunities (O) & SO1 & $\begin{array}{l}\text { Increasing the promotion of Menjangan Island } \\
\text { and Pemuteran tourism by optimizing more } \\
\text { inclusive annual cultural festival activities }\end{array}$ & WO1 & $\begin{array}{l}\text { Optimizing local community involvement in annual } \\
\text { cultural festival activities }\end{array}$ \\
\hline & SO2 & $\begin{array}{l}\text { Facilitating tourists and donors to be involved } \\
\text { in coral reef conservation }\end{array}$ & WO2 & $\begin{array}{l}\text { Making regulations related to local fishing activities and } \\
\text { zoning for marine use }\end{array}$ \\
\hline Threats (T) & ST1 & $\begin{array}{l}\text { Creating an institution that facilitates diving to } \\
\text { set standard prices and quality of service }\end{array}$ & WT1 & $\begin{array}{l}\text { Outreaching to local communities and early tourism } \\
\text { education, tourism skills training, and English }\end{array}$ \\
\hline & ST2 & $\begin{array}{l}\text { The role of local government in enforcing } \\
\text { business permits and divemaster screening }\end{array}$ & WT2 & $\begin{array}{l}\text { Collaborating with dive businesses and local } \\
\text { communities in waste management and beach clean-ups }\end{array}$ \\
\hline & & & WT3 & $\begin{array}{l}\text { The government's role in tourism operational } \\
\text { certification with the new normal mechanism }\end{array}$ \\
\hline
\end{tabular}

The beauty of the Menjangan Island is the main cause of attraction for tourists in Pemuteran Village. The island has a lot of diving centers and it is a great place for diving and snorkeling activities. Moreover, the village itself is a supporting area for various tourism service providers such as dive centers, resorts, and other tourism support services (Marfai et al., 2020).

The village also has a lot of local culture and social-cultural activities that most tourists can use to gain new experiences. The existence of biorock as a forum for coral conservation which has been going on for a long time is also an internal force that supports the sustainable aspects of coral reef tourism. According to the SWOT analysis conducted, the weaknesses of 
the study include any and all factors that hinder the development of a sustainable diving tourism sector in Pemuteran. In addition, the involvement of local communities is still not enough to support tourism development in Pemuteran Village. Community involvement is still limited to certain groups such as dive entrepreneurs, homestays, restaurants, and traders. These groups of individuals are local people that take advantage of tourism activities. Moreover, there are still a lot of local people that do not feel responsible and take part in such activities. Therefore, it is necessary to expand the service sector and other potential roles of tourist service providers, so as to support tourism in general. Thus, local communities should focus more on providing tourism services such as tour guides, cultural exhibitions, and the other daily needs of tourists. The problem of garbage disposal, illegal fishing, and domestic waste is still a weakness that can disrupt the preservation of coral reefs and marine life. External factors include opportunities and threats that may affect the development of Pemuteran diving tourism activities. These opportunities include an increase in the number of tourists in the last few decades and promotional efforts in the form of cultural festivals that have not been optimally utilized. The use of technology and social media is also a strategic choice to widen the market effectively and inclusively (Scholtz and Kruger, 2020). However, some of the threats experienced in the development of tourism activities in Pemuteran include unfair price competition (Gerungan and Chia, 2020), entry of new and unlicensed diving centers, and the presence of a large number of unlicensed diving instructors and staffs. The impact of the pandemic has also become a major problem or threat to tourism and tourist activities (Haywood, 2020), in Pemuteran. Its effect was felt by almost every tourist in the Pemuteran community. This impact will still be felt for a very long time, especially if there is no effort to adopt new habits after the epidemic.

Furthermore, through the identification of SWOT factors, strategic policies can be formulated by local policy makers in developing tourism (Sutikno et al., 2018; Harianto et al., 2020). This study aimed to analyze the various problems associated with tourism based on the point of view of the dive center operator. The SWOT indicator used in the study was subjected to the respondent's understanding and opinions on tourism (Liu et al., 2019). The formulation of strategies is also influenced by the ability of the researcher to understand the topic at hand. Strategy formulation in Pemuteran tourism development is made in the SWOT matrix and its priority as shown in Table 8 and Figure 10. A massive promotion or public awareness of the Menjangan Island may increase market interest, both locally and internationally. The annual cultural festival can be used as an effort to promote diving and snorkeling tourism as well as various local cultural exhibitions. So far, the benefits of this annual agenda have not been entirely felt by the respondents. Therefore it is necessary to restructure the festival agenda and mechanism by involving more parties, especially local communities.

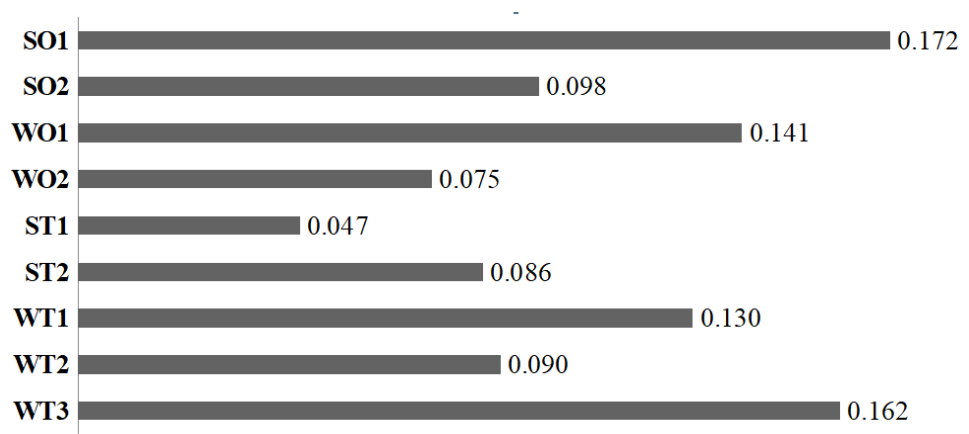

Figure 10. Priority of strategies

The involvement of various stakeholder elements is key in formulating policies and strategies for developing diving tourism in Pemuteran. Local government has an important role in creating a regulatory legality needed to regulate and guarantee various interests (Winther et al., 2020; Wondirad et al., 2020; Bennett et al., 2019; Klinger et al., 2018; Casari and Tagliapietra, 2018). Various roles such as enforcement of diving tourism business permit regulations, pricing, and minimum operational standards can be important contributions from local governments.

The increasing number of diving centers that are established without legal permits and do not comply with the set standards, is a trigger for unfair price competition (Gerungan and Chia, 2020). This may inevitably cause the creation of an environment that is less accommodating to collaborations among various stakeholders (Gerungan and Chia, 2020; Marconi et al, 2020). Revitalization and local government support for local tourism awareness organizations or groups are also needed to further legalize the institution's role in relation to tourism mechanisms and management. The impact of the pandemic should also strengthen the role of local governments to regulate new habitual arrangements for dive tourists. It should also prompt the need to guarantee trust and security for all tourists, during recreation with various adaptations to new habits.

Community involvement is also the key to success in creating a conducive tourism atmosphere. Local people that are more contributive and feel involved in tourism can create a friendly and comfortable environment for local and international tourists. In order to expand the role of local communities, it is necessary to develop the sectors and potential organisations that can support the needs of these tourists. Socialization of the community and provision of skills such as training in diving and English should be given more attention. If possible, various governments should adopt tourism education into their basic curriculum and improve tourism vocational education for local youth.

\section{DISCUSSION}

In Partelow and Nelson's (2018) study, a dive center network analysis was carried out on a small tourist island where socio-ecological characteristics play a role in the interdependence relationship between factors. The ecological conditions of small islands make it necessary to import various goods and develop their own public services (Partelow \& Nelson, 2018). Pemuteran, which is located on the north coast of Bali, is a local village with rural characteristics where its socio-cultural customs play a greater role in the collaborative relationship between business owners. The characteristics of rural sociocultural areas are identical to how traditional societies show social relations that are more personal, direct, and tied to the 
same belief and values (Tonnies, 1999). However, in this study, the collaborative relationship in the dive center business network system is more dominant in the form of instrumental and formal relationships which represent a typical modern society. The nationality of owners also appear to be constraining factor in the informal collaboration between local and nonlocal dive center business owners. According to the social network analysis of dive center business owners in Pemuteran, the results show that business owners only come together so that they can achieve a common goal. Simmel (1955) explained the homophile phenomenon in social relations. The results of the research explained that people only associate with other people when they have similar interests, goals, and have the same characteristics. The similarity of these characteristics can be in the form of interests, hobbies, political aspirations, ideologies, and backgrounds (Ruiz et al., 2020; Ruef, 2002). In this case, the owner's national background becomes a hindrance in collaboration strategies thus, this ultimately results in various operational problems in the tourist business. The problems may include price competition and commitment to protecting the marine environment together. The idea of being owners of the same business that utilizes a shared sea area, should be sufficient enough to facilitate good collaborative relationships and operations needed in protecting tourist sites (Dimmock and Musa, 2015). This is because, any damage or loss that affects the sustainability of these areas of tourist attraction, the effect will be experienced by every business owner and not by a particular group. Therefore, it is necessary to prioritize environmental conservation and sustainability of tourism ecosystems as common main goals (Trialfhianty and Suadi, 2017; Gerungan and Chia, 2020; Marconi et al., 2020). PET (Pemuteran Environmental Tourism), which consists of non-local dive centers, is an indication of the lack of common commitment in the protection and conservation of tourism areas between local and non-local center operators. In addition, it is also necessary to know how socio-cultural barriers affect or hinder collaboration between local and non-local owners of the centers.

\section{CONCLUSIONS}

The dive centers in the Pemuteran tourism area can be identified based on several characteristics such as the nationality of the owner, the services provided, the diving certification body, and the number of staffs present. Based on services offered, dive centers are grouped into dive shops that only permit the rental of diving equipment and guides, and centers that offer homestay services in the form of a dive resort. In addition, based on nationality, the owners of the centers are mostly dominated by local individuals while some are dominated by non-locals from various countries. Judging from the size of the business and the number of working personnel, dive centers are mostly grouped into medium-sized businesses. PADI is the most preferred institution for the certification of diving business centers in Pemuteran.

The analysis of social networks among dive center businesses in Pemuteran tourism show distinctive collaboration characteristics related to operational and conservation activities. The network analysis conducted on the dive centers in Pemuteran show a centralized collaboration network pattern. This type of collaboration then shows the relationship between stains/actors that focus on a particular business owner. Central actors usually have more angles/relationships in the dive center collaboration network in Pemuteran, and they are mainly influenced by how long the centers have been in existence and the ownership of the boat. Boat ownership as a determining factor for collaboration between owners indicates an operational partnership. Collaborative relationships in conservation of coral reefs have also occurred with the formation of several institutions such as PET (Pemuteran Environmental Trust), the Tourism Awareness Group (Pokdarwis), and Biorock. The spatial factor or the proximity between dive centers is not considered to have a significant effect on collaboration between any centers in general. The characteristics of dive center collaboration patterns in Pemuteran tourism indicate a lack of optimal collaboration from stakeholders, especially between dive centers with local and non-local ownership. The socio-cultural characteristics of the owner's nationality are considered as one of the inhibiting factors for collaboration between local and non-local business owners. This difference in nationality could be assessed in further studies.

Pemuteran dive tourism development strategies are formulated based on a SWOT analysis of the internal and external factors derived from the point of view of owners of dive centers in Pemuteran. Problems such as price competition and illegal diving are a threat that many of these centers complain about. Furthermore, the role of local government is needed to ensure the legality of regulations that can be obeyed by all stakeholders (Agrawal, 2003). Lack of public awareness to engage in tourism is also an obstacle that affects the creation of a conducive tourist environment. In addition, the community also has an important role to play in maintaining a sustainable and tourist-friendly environment. Conclusively, the involvement of the government and local communities is the key to success in the sustainable management and development of Pemuteran tourism.

\section{Acknowledgement}

This research was funded by Universitas Gadjah Mada through the Master's Thesis Research scheme (Hibah PTM/Penelitian Thesis Magister), Ristekdikti. The author thanks everyone that has contributed to the success of this paper, including the owners and managers of the dive centers in Pemuteran, Buleleng, Bali. The author would also like to thank the Pemuteran traditional village government, Biorock conservation managers, the tourism awareness group (Pokdarwis), and all Pemuteran residents for their generosity in facilitating the authors in completing this research. The author also hopes that this research can trigger further studies related to network analysis and sustainable tourism.

\section{REFERENCES}

Agrawal, A. (2003). Sustainable governance of common-pool resources: context, methods, and politics. Annual Review of Anthropology, 32, 243-262. https://doi.org/10.1146/annurev.anthro.32.061002.093112.

Albrecht, J.N. (2013). Networking for sustainable tourism-towards a research agenda. Journal of Sustainable Tourism, $21(5), 639-657$. https://doi.org/10.1080/09669582.2012.721788 
Baggio, R., Scott, N., \& Cooper, C. (2010). Improving tourism destination governance: Acomplexity science approach. Tourism Review, 65(4), 51-60. https://doi.org/10.1108/16605371011093863

Bennett, N.J., Cisneros-Montemayor, A.M., Blythe, J., Silver, J.J., Singh, G., Andrews, N., Calò, A., Christie, P., Di Franco, A., Finkbeiner, E.M., Gelcich, S., Guidetti, P., Harper, S., Hotte, N., Kittinger, J.N., Le Billon, P., Lister, J., López de la Lama, R., McKinley, E., \& Sumaila, U.R. (2019). Towards a sustainable and equitable blue economy. Nature Sustainability, 2(11), 991-993. https://doi.org/10.1038/s41893-019-0404-1

Blicharska, M., Smithers, R.J., Mikusinski, G., Ronnback, P., Harrison, P.A., Nilsson, M., \& Sutherland, W.J. (2019). Biodiversity's contributions to sustainable development. Nature sustainability, 2, 1083-1093. https://dx.doi.org/10.1038/s41893-019-0417-9

Bodin, O. (2017). Collaborative environmental governance: achieving collective action in social-ecological systems. Science, 357, 1114, https://doi.org/10.1126/science.aan 1114

Cahyadi, F.D., Khakhim, N., \& Mardiatno, D. (2018). Integrasi SWOT dan AHP dalam Pengelolaan Ekosistem Mangrove di Kawasan Wisata Bahari Gugusan Pulau Pari [Integration of SWOT and AHP in Mangrove Ecosystem Management in the Marine Tourism Area of the Pari Island Cluster]. Jurnal Pariwisata Pesona, 3(2), 105-118, (in Bahasa). http://jurnal.unmer.ac.id/index.php/jpp/article/view/2336

Casari, M., \& Tagliapietra, C. (2018). Group size in social-ecological systems. Proceedings of the National Academy of Sciences, 115(11), 2728-2733. https://doi.org/10.1073/pnas.1713496115

Cehan, A., Eva, M., Latu, C., \& Costa, C. (2020). Inquiring Structure and Forms of Collaboration in Tourism through Social Network Analysis. Sustainability, 12, 8161. https://doi.org/10.3390/su12198161

Chung, S.S., Au, A., \& Qui, J.W. (2013). Understanding the underwater behaviour of SCUBA divers in Hong Kong. Environmental Management, 51, 824-837. https://doi.org/10.1007/s00267-013-0023-y

Dearden, P., Bennett, M., \& Rollins, R. (2007). Perceptions of diving impacts and implications for reef conservation. Coastal Management, 35(2-3), 305-317. https://doi.org/10.1080/08920750601169584

Dimmock, K., \& Musa, G. (2015). Scuba Diving Torism System: A Framework for collaborative management and sustainability. Marine Policy, 54, 52-58. https://doi.org/10.1016/j.marpol.2014.12.008

Dimopoulos, D., Queiros, D., \& Zyl, C.V. (2019). Sinking deeper: The most significant risks impacting the dive tourism industry in the East African Marine Ecoregion. Ocean and Coastal Management, 181, 104897. https://doi.org/10.1016/j.ocecoaman.2019.104897

Dredge, D. (2006). Networks, Conflict and Collaborative Communities. Journal of Sustainable Tourism, 4(6), 562-581. https://doi.org/10.2167/jost567.0

Febriansyah, I., Anusgroho, A.D.S., \& Helmi, M. (2012). KajianKerentananPantai Di Pesisir Kabupaten Cilacap, Jawa Tengah. Journal of Oceanography, 1(2), 139-148. https://ejournal3.undip.ac.id/index.php/joce/article/view/4153/4025

Franco, M.C., Ona, M.S., \& Lopez, C.C. (2019). Segmentation and motivations in eco-tourism: The case of a coastal national park. Ocean and Coastal Management, 178, 104812. https://doi.org/10.1016/j.ocecoaman.2019.05.014

Garcia-Hernandez, C., Ruiz-Fernandez, J., \& Serrano-Canades, E. (2020). Social Network Analysis in Geoscience: Scientific Collaboration Between Periglacial Scholars in the Iberian Peninsula (2000-2017). Geographical Research Letters, 46(1), 319-339. https://doi.org/10.18172/cig.vol46iss1

Gerungan, A., \& Chia, K.W. (2020). Scuba diving operators' perspective of scuba diving tourism business in Nusa Penida, Indonesia. Journal of Outdoor Recreation and Tourism, 31, 100328. https://doi.org/10.1016/j.jort.2020.100328

Giglio, V.J., Luiz, O.J., \& Ferreira, C.E.L. (2020). Ecological impact and management strategies for recreational diving: A review. Journal of Environmental Management, 256, 109949. https://doi.org/10.1016/j.jenvman.2019.109949

Guzner, B., Novplansky, A., Shalit, O., \& Chadwick, N.E. (2010). Indirect impacts of recreational SCUBA diving: patterns of growth and predation in branching stony corals. Bulletin Marine Science, 86,727-742. http://wp.auburn.edu/chadlab/wp-content/uploads/ 2015/10/guzner-et-al-2010-bmsci.pdf

Ha, N.T., Cong, L., \& Wall, G. (2020). China's scuba divers' marine-based environmental behaviors. Journal of Sustainable Tourism, 1-23, Routledge: Taylor \& Franci Group. https://doi.org/10.1080/09669582.2020.1820016

Harianto, S.P., Masruri, N.M., Winarno, G.D., Tsani, M.K., \& Santoso, T. (2020). Development strategy for ecotourism management based on feasibility analysis of tourist attraction objects and perception of visitors and local communities. Biodiversitas, 21(2), 689-698. https://doi.org/10.13057/biodiv/d210235

Haywood, K.M. (2020). A post COVID-19 future - tourism re-imagined and re-enabled. Tourism Geographies, $22(3)$, 599-609. https://doi.org/10.1080/14616688.2020.1762120

Hughes, T.P., Barnes, M.L., Bellwood, D.R., Cinner, J.E., Cumming, G.S., Jackson, J.B.C., Kleypas, J., van de Leemput, I.A., Lough, J.M., Morrison, T.H., Palumbi, D.R., vanNes, E.H., \& Scheffer, M. (2017). Coral reefs in the Anthropocene. Nature, 546, 82-90. http://dx.doi.org/10.1038/nature22901

Jamison, N. (2009). The role of biorock artificial coral reefs in the sustainable governance of marine protected areas: a case study of Pemuteran, Bali, 60 p., M.Sc Thesis, Sustainability and Management Programme, Department of Geography, Royal Holloway College, University of London. https://link.springer.com/article/10.1007/s11852-017-0553-1

Klinger, D.H., Eikeset, A.M., Davidsdottir, B., Winter, A.M., \& Watson, J.R. (2018). The mechanics of blue growth: management of oceanic natural resource use with multiple, interacting sectors. Marine Policy, 87, 356-362. https://doi.org/10.1016/j.marpol.2017.09.025

Kurniawan, A., Susanti, F., \& Yunianti, S.R. (2020). Strategy to develop tourism objects at Ijobalit, a former pumice mine in East Lombok. IOP Conf. Series: Earth and Environmental Science, 413, 012028. https://iopscience.iop.org/article/10.1088/1755-1315/413/1/012028

Liu, R., Wang, Y., Qian, Z. (2019). Hybrid SWOT-AHP Analysis of Strategic Decisions of Coastal Tourism A Case Study of Shandong Peninsula Blue Economic Zone. Journal of Coastal Research, SI, 94, 671-676. https://www.jstor.org/stable/26854025

Lu, X., Yao, S., Fu, G., Lv, X., \& Mao, Y. (2019). Dynamic simulation test of a model of ecological system security for a coastal tourist city. Journal of Destination Marketing \& Management. https://doi.org/10.1016/j.jdmm. 2019.05.004

Lyons, P.J., Arboleda, E., Benkwitt, C.E., Davis, B., Gleason, M., Howe, C., Mathe, J., Middleton, J., Sikowitz, N., Untersteggaber, L., \& Villalobos, S. (2015). The effect of recreational SCUBA divers on the structural complexity and benthic assemblage of a Caribbean coral reef. Biodiversity Conservation, 24, 3491-3504. https://doi.org/10.1007/s10531-015-1009-2

Marconi, M., Giglio, V.J., Filho, G.H., \& Motta, F.S. (2020). Does quality of scuba diving experience vary according to the context and management regime of marine protected areas? Ocean and Coastal Management, 194, 105246. https://doi.org/10.1016/j.ocecoaman.2020.105246

Mardiatno, D., \& Mutaqin B.W. (2011). Spatio-temporal Modelling of Population Distribution for the Tsunami Risk Assessment in Pacitan, Indonesia. The Investigation Report of 2004 Northern Sumatra Earthquake (Additional Volume) - Graduate School of Environmental Studies, Nagoya University, Nagoya, Japan.

Marfai, MA., (2014). Impact of sea level rise to coastal ecology: A case study on the northern part of java island, Indonesia. Quaestiones Geographicae, 33(1): 107-114. https://doi.org/10.2478/quageo-2014-0008 
Marfai, M.A., Ahmada, B., Mutaqin, B.W., \& Windayati, R. (2020). Dive resort mapping and network analysis: Water resources management in Pemuteran coastal area, Bali-Indonesia. Geographia Technica, 15(2),106-116. http://dx.doi.org/10.21163/GT_2020.152.11

Marfai, M.A., Almohammad, H., Dey, S., Susanto, B., \& King, L. (2008). Coastal dynamic and shoreline mapping: Multi-sources spatial data analysis in Semarang Indonesia. Environmental Monitoring and Assessement, 142(1-3), 297-308. https://doi.org/10.1007/s10661-007-9929-2

Marfai, M.A., Riasasi, W., \& Suriadi. (2019). Role of disaster preparedness and climate change mitigation on the assessment of coastal disaster resilience in Brebes. Proceedings of SPIE - The International Society for Optical Engineering, 11372. https://doi.org/10.1117/12.2541609

Nguyen, T.Q.T., Young, T., Johnson, P., \& Wearing, S. (2019). Conceptualising networks in sustainable tourism development. Tourism Management Perspectives, 32, 100575. https://doi.org/10.1016/j.tmp.2019.100575

Ong, T.F., \& Musa, G. (2011). An examination of recreational divers underwater behaviour by attitude-behaviour theories. Current Issues in Tourism, 14(8), 779-795. https://doi.org/10.1080/13683500.2010.545370

Otte, E., \& Rousseau, R. (2002). Social network analysis: A powerful strategy, also for the information sciences. Journal of Information Science, 28(6), 441-453. https://doi.org/10.1177\%2F016555150202800601

Palma, M., Magliozzi, C., Casado, M.R., Pantaleo, U., Fernandes, J., Coro, G., Cerrano, C., \& Leinster, P. (2019). Quantifying coral reef composition of recreational diving sites: A structure from motion approach at seascape scale. Remote Sensing, 11(24). https://doi.org/10.3390/rs11243027

Partelow, S. \& Nelson, K. (2018). Social network, collective action and the evolution of governance for sustainable tourism on the Gili Islands, Indonesia. Marine Policy, 112. https://doi.org/10.1016/j.marpol.2018.08.004

Plummer, R., \& Fennell, D. (2009). Managing protected areas for sustainable tourism: prospects for adaptive co-management. Journal Sustainable Tourism, 17(2), 149-68. https://doi.org/10.1080/09669580802359301

Richmond, M.D. (Ed.). (2011). A Field Guide to the Seashores of Eastern Africa and the Western Indian Ocean Islands. Sida/WiOMSA, 494, 9987-8977-9-7. https://www.jstor.org/stable/4314404

Ruef, M. (2002). A Structural event approach to the analysis of group composition. Social Networks, 24(2), 135-160. https://doi.org/10.1016/S0378-8733(01)00054-5

Ruiz, D., Campos, J., \& Finke, J. (2020). Dynamics in Affinity-Weighted Preferential Attachment Network. Journal of Statistical Physics, 181, 673-689. https://doi.org/10.1007/s10955-020-02594-0

Scholtz, M. \& Kruger, M. (2020). From drifters to followers: a CIA-typology for engaging followers of scuba dive operators' Facebook pages. Current Issues in Tourism, Routledge: Taylor \& Franci Group. https://doi.org/10.1080/13683500.2019.1615039

Scott, J. (2000). Social network analysis: A handbook, Sage Publications, London, UK.

Scott, N., Baggio, R., \& Cooper, C. (2008). Network analysis and tourism: From theory to practice, 35. Channel View Publications. https://doi.org/10.21832/9781845410896

Setyoko, A.T., \& Kristiningrum, E. (2019). Analysis of Dive Industry Minimum Requirement Criteria Based on Risk Management. IOP Conference Series: Materals Science and Engineering, 598, 012050. https://iopscience.iop.org/article/10.1088/1757-899X/598/1/012050

Simmel, G. (1955). Conflict and the Web of Group Affiliations. Free Press, Glencoe, IL (K. Wolff, R. Bendix, Trans.: original work published in 1923)

Spalding, M., Burke, L., Wood, S.A., Ashpole, J., Hutchison, J., \& Ermgassen, P. (2017). Mapping the global value and distribution of coral reef tourism. Marine Policy 82, 104-113. https://doi.org/10.1016/j.marpol.2017.05.014

Sriartha, I.P., \& Giyarsih, S.R. (2015). Spatial Zonation Model of Local Irrigation System Sustainability (A Case of Subak System in Bali). Indonesian Journal of Geography, 47(2),142-150. https://doi.org/10.22146/ijg.9253

Suprayogi, S. Mutaqin, B.W., Widyaningsih, Y., Jayanto, G.D., Umarella, M.R., \& Marfai, M.A. (2020). Preliminary River Morphometry Analysis for Rafting Tourism in the Saba River, Bali Islands, Indonesia. International Journal of Sustainable Development and Planning, 15(5), 631-638. https://doi.org/10.18280/ijsdp.150505

Sutikno, Yusuf, M., Soedarso, Sukardi, \& Azmi, D.A. (2018). Integrated coastal tourism development strategy in Parigi Moutong, Central Sulawesi. IOP Conf. Series: Earth and Environmental Science, 202, 012041. https://iopscience.iop.org/article/10.1088/1755-1315/202/1/012041

Tonnies, F. (1999). Community and Society. Routledge Taylor \& Francis Group (Originally published in 1980 by Basic Books, Inc. Publishers), New York, USA.

Trialfhianty, T.I., \& Suadi (2017). The role of the community in supporting coral reef restoration in Pemuteran, Bali, Indonesia. Journal of Coastal Conservation, 21(6), 873-882. https://doi.org/10.1007/s11852-017-0553-1

Wasserman, S., \& Galaskiewicz, J. (1994). Advances in social network analysis: Research in the social and behavioral sciences, Sage Publication, Thousand Oaks, USA. http://dx.doi.org/10.4135/9781452243528

Windayati, R., Marfai, M.A., Pangaribowo, E.H., \& Mardiatno, D. (2020). Potential, suitability, and carriying capacity of coral reef ecosystem in West Buleleng MPA. IOP Conference Series: Earth and Environmental Science, 584, 012048.

Winther, J.G., Dai, M., Rist, T., Hoel, A.H., Li, Y., Trice, A., Morrissey, K., Menez, M.J., Fernandes, L., Unger, S., Scarano, F.R., Halpin, P., \& Whitehouse, S. (2020). Integrated ocean management for a sustainable ocean economy. Nature ecology \& evolution. https://doi.org/10.1038/s41559-020-1259-6

Wondirad, A., Tolkach, D., \& King, B. (2020). Stakeholder collaboration as a major factor for sustainable ecotourism development in developing countries. Tourism Management, 78, 104024. https://doi.org/10.1016/j.tourman.2019.104024

Zheng, W., Cai, F., Chen, F., Zhu, J., Qi, H., Cao, H., \& Zao, S. (2020). Beach management strategy for small islands: Case studies of China. Ocean and Coastal Management, 184, 104908. https://doi.org/10.1016/j.ocecoaman.2019.104908

*** Buleleng in Figures (2019). Buleleng in Figures 2019 (Indonesia: BPS of Buleleng District). https://bulelengkab.go.id/bankdata/ kabupaten-buleleng-dalam-angka-2019-74

Article history: Received: 26.01.2021 Revised: 05.04.2021 Accepted: 08.06.2021 Available online: 30.06 .2021 